\title{
The Effect of the Maqashid Sharia Index, Company Size, and Company Age on Islamic Social Reporting
}

\author{
Vivi Nor Khoiriyah ${ }^{1}$, Kautsar Riza Salman ${ }^{2} *$ \\ ${ }^{1,2}$ STIE Perbanas Surabaya, Indonesia
}

Submitted: 12 May 2020; Accepted: 19 December 2020; Published: 23 December 2020

\begin{abstract}
Islamic social reporting is the application of social functions that are based on sharia provisions. It does not only help the Muslims in deciding but also helps companies to fulfill their obligations to God and the community. This study aims to obtain empirical evidence on the influence of maqashid sharia index, company size, and company age on Islamic social reporting and the example is the 11 sharia banks in Indonesia. This study takes about 4 years (2015-2018) and the analysis technique was a descriptive and statistical analysis. Statistical analysis uses the Partial Least Square approach (Smartpls version 3.0) and the result is indicated that the maqashid sharia index, company size, and company age have a positive effect on Islamic social reporting. This study empirically proves that a sharia bank that is able to express the maqashid sharia index well then has good Islamic social reporting disclosure. The sharia banks that have high total assets and income tends to make an extensive Islamic social reporting disclosures because there are also more sources of funds used to make disclosures. The longer sharia bank is established, the higher level of Islamic social reporting disclosure.
\end{abstract}

Keywords: maqashid sharia index, company size, company age, Islamic social reporting 


\section{INTRODUCTION}

Indonesia banking policy was decided by the government since the establishment of the Islamic bank that its implementation was regulated in various applicable laws and regulations (Salman, Anshori, \& Tjaraka, 2018). The country uses a dual banking system and that of sharia banking is consistent with Islamic legal principles and guided by Islamic economics. Islamic economics is a body of knowledge that help to realize human welfare through the allocation and distribution of scarce resources following Islamic teachings. The sharia banking provide interest-free services to its customers because payment and withdrawal of interest are prohibited in all forms of transactions and even, Islam forbids Muslims from attracting and paying interest (usury). This prohibition distinguishes sharia and conventional banking systems (Usman \& Khan, 2012). The development of sharia banking in Indonesia is an embodiment of public demand that requires another banking system in providing sound banking or financial services, also meets sharia principles(Syukron, 2013).

Merely looking at sharia banking today, it has improved and develop better performance to create good trust in society and attract public interest in using the bank. Sharia banking is not only seen from its financial performance but also from the application of social functions or corporate social responsibility (CSR) performed to stakeholders.

According to Firdaus (2017), International Regulatory Institutions such as AAOIFI (Accounting and Auditing of Islamic Financial Institutions) have set standards in the disclosure of sharia banking social responsibility. As a sharia entity, sharia banks are meant to pay attention to the community environment as a form of concern and responsibility of the people. Assessment CSR in sharia banking uses an index Islamic social reporting which is a starting point in disclosing Corporate Social Responsibility (CSR). The use of this index has been adjusted to the AAOIFI standard which was later developed by several researchers such as Haniffa and Hudaib (2007), Othman, Thani, and Ghani (2009). The Islamic social reporting was first put forward by researchers from Malaysia, Haniffa in 2002, then developed by Maali, Casson, and Napier (2006) and Othman et al (2009) in Malaysia. Haniffa (2002) stated that there are limitations in conventional social reporting and now reveal the conceptual framework of Islamic social reporting based on sharia provision. This provision does not only help the Muslims in making a decision but also helps companies in fulfilling their obligations to Allah SWT and the surrounding community. Maali et al. (2006) conducted a content analysis of actual social disclosures in the annual reports of 29 Islamic banks in 16 countries. His findings show that social reporting in Islamic banks is far below expectations and also banks that pay zakat provide more social disclosures than banks that do not pay. 
Several studies conducted by Lestari (2013 and 2016), Saoqi (2017), Salman et al (2018), and Ummiyati and Baiquni (2018) examined the effect of independent variables on Islamic social reporting with different results. However, this study provides empirical evidence on the effect of the maqashid sharia index, company size, and company age on Islamic social reporting, for example, the 11 sharia banks. The analysis technique uses descriptive and statistical analysis using SmartPLS version 3.0 as data processing.

The purpose of this study is to determine the effect of the maqashid sharia index on Islamic social reporting. Also, it aims to determine the effect of company size and company age on Islamic social reporting.

\section{Legitimacy Theory}

Legitimacy is a process that leads to a company considered legitimate. The company strives to ensure that they operate within the limits and norms of the community's respective activities which are considered legal. The legitimacy of the community is an important factor for the company to continue to survive and develop as a vehicle in constructing the company's strategy, and how they position themselves to develop in community environment (Hadi, 2009).

The theory of legitimacy implies that Islamic social reporting conducted by companies or sharia banking tends to get positive values and legitimacy from the public. The legitimacy sharia companies and banks gain from the public helps them to continue to survive and develop in society and benefit in the future.

Legitimacy theory tends to explain the effect of the maqashid sharia index on Islamic social reporting. Based on this theory, especially on socio-political legitimacy, organizational results are in the form of financial performance and the maqashid sharia index. Referring to this, it tends to be explained that companies with high financial performance and maqashid sharia index are more in line with social norms through the disclosure of broader corporate social responsibility information.

Legitimacy theory strives to explain the effect of firm size on Islamic social reporting. According to this theory, the existence of a company depends on the acceptance of the community in which the company operates. This is possible because companies are influenced by society, and vice versa. Legitimacy from the community is assumed to be an important resource for companies in determining business sustainability (Deegan, 2002).

\section{Stakeholder Theory}

Stakeholder theory describes the particular parties that the company is responsible for and also discusses matters relating to the interests of various parties. Based on stakeholder 
theory, companies have responsibilities to all individuals or each group that has been affected by the obligations held by them (Ummiyati \& Baiquni, 2018).

Stakeholders basically control themselves or have the ability to influence the use of economic resources used by the company. This is determined by the size of the power possessed by stakeholders over the economic resources. The power is the ability to limit the use of limited economic resources (capital and labor), access to the affected media, the ability to regulate and influence the consumption of goods and services produced by the company (Deegan, 2002).

Stakeholder theory is the basic theory that forms the foundation of Islamic social reporting which deals with disclosure of corporate social responsibility to stakeholders, including investors, employees, and the community. This theory explains the influence of the maqashid sharia index, company size, and company age on Islamic social reporting. In this context, the better the maqashid sharia index, the wider the social reporting disclosed by Islamic banks. Besides, the larger the size of the company, the wider the social reporting disclosed by Islamic banks. Likewise, the longer the company has been established, the wider the disclosure of social responsibility will be because there is more time for the company to recognize and have an impact on the environment.

\section{Maqashid Sharia Index}

The concept of the maqashid sharia index is taken from the understanding of maqashid sharia which is interpreted as the ultimate goal of sharia known as the value of well-being and benefits as well as eliminating suffering. The maqashid framework of sharia has five elements consisting of protecting religion, life, reason, descent, and property (Saoqi, 2017) and they are formed to create benefits in life. Besides, the maqashid sharia index is used to measure the performance of sharia banks in disclosure of social responsibility. This measurement is useful in the performance of sharia banking which was developed based on the principles of maqashid with the aim that there is a measurement for sharia banks following its objectives. Maqashid sharia index is grouped into three categories namely education, justice, and benefits (Mohammed, Razak, \& Taib, 2008).

The first category is education, each individual must have knowledge and expertise to increase their spiritual values. Sharia banks is able to design education and training programs with moral values, so that they will be able to increase their knowledge and expertise to employees. The bank also provides information to stakeholders that the products offered are by Islamic regulations. Education indicators have 4 (four) ratios namely education, research, training, and promotion. 
In second category, namely justice, Sharia banks ensure honesty and fairness in all transactions and business activities. The indicator of justice is illustrated by 3 (three) ratios namely fair return, distribution function, and interest-free income. The contract must be free from elements of injustice such as maysir, gharar, and usury. This category of justice is explained in Surah AlBaqarah Verse 278: "O you who believe, fear Allah and leave the rest of usury (which has not been collected) if you are a believer" (Surah Al-Baqarah $(02) ; 278)$. The verse explains that Allah SWT strongly forbids the collection of usury in all transactions because usury is very detrimental to many parties.

Also, in the third category which is benefits (maslahah), Sharia banks develop investment and social services to improve the welfare of the community. This is seen from the profitability ratio of banks, zakat and investment. The creation of benefits in Sharia banks prioritize the common interest rather than profit-oriented.

\section{Company Size}

Company size is the variable most often used in making annual reports and it affects the company's financing structure. Generally, a larger scale company will tend to disclose more information about increased ownership due to high dividend receipts (Dewi \& Wirajaya, 2013). The size of the company ratio is measured using total assets and income. Total assets are chosen as a way to calculate the size of a company by considering the value of assets that are relatively more stable than sales. A company that has grown and developed is a reflection that it has a large total assets. Indicators in company size are seen from total revenue, market capitalization, and total assets and the greater they are, the greater the size of the company. Companies that have a large total income, the company make a maximum turnover of money. There is a relationship between company size and Islamic social reporting. According to Lestari (2013), Islamic social reporting in annual reports has a significant relationship with company size. Specifically, a higher disclosure value is carried out by large, well-performing companies.

\section{Company Age}

The company was founded to be able to last a very long time or not limited. The age of the company is something that investors consider before investing their capital in it. The measurement of company age is calculated from the time the company was established until the observation data (annual report). The annual report published by the company will reveal how good the company's ability is in maintaining stability and the company's image. 
The age of the company is estimated to have a positive relationship with the disclosure of corporate social responsibility. Utami and Prastiti (2011) stated that the longer the company lasts, it means that more information has been obtained by the public about the company. According to Lestari (2013) the age of the company is a representative of the period of the company in the industry. The age of the company can be measured by the length of time the company has been established.

\section{Islamic Social Reporting}

Islamic social reporting (ISR) was mentioned by Roszaini Haniffa in 2002 in an article entitled "Social Reporting Disclosure of an Islamic Perspective" which is the development of the sharia framework. This framework became the basic foundation for the formation of Islamic social reporting comprehensive and produce material, moral and spiritual aspects in the company.

The Islamic social reporting Index is an extension of social reporting that includes public expectations about the role of companies in spiritual perspectives and not only in the economy. Besides, the Islamic social reporting index also emphasizes social justice related to reporting on the environment, minority rights, and employees (Fitria \& Hartanti, 2010). Islamic social reporting has five themes namely finance and investment, products and services, employees, the community, and the environment (Haniffa, 2002).

Some previous empirical research on Islamic social reporting gave inconsistency results on the effect of company size. Rama and Meliawati (2014), Sunarsih and Ferdiyansyah (2017) succeeded in proving the positive influence of company size on the level of Islamic social reporting. Also, the research of Dienes and Velte (2016) found a negative effect and that of Juhmani (2014), Wiyuda and Pramono (2017) failed to prove the of company size on the level of corporate social responsibility disclosure.

\section{The Effect of Maqashid Sharia Index on Islamic Social Reporting}

The influence of maqashid sharia index on Islamic social reporting is explained by legitimacy theory which states that for company to be accepted by society, it tends to fulfill social contracts through the disclosure of economic, social, and political information. Based on the theory of organizational socio-political legitimacy it is a financial performance and Islamic maqashid index. Companies that have good Islamic financial performance and maqashid index have social norms through disclosure of broader social responsibility. Also, it tends to express social responsibility at a higher level to gain trust of the people so that they are able to maintain future performance (Salman et al, 2018). 
Salman et al (2018) revealed that the maqashid sharia index has a positive impact on the level of corporate social responsibility disclosure. Companies that perform well tend to express social responsibility at a higher level to gain trust from the community to be able to maintain future performance. The current study again tested the consistency with previous studies, namely Salman et al. (2018), with a different and more up-to-date time frame. He used the 20102016 research period, while the current research uses that of 2015-2018. This research formulates the hypothesis as follows:

$\mathbf{H}_{1}$ : The Maqashid Sharia Index influences Islamic Social Reporting.

\section{Effect of Company Size on Islamic Social Reporting}

The size of the company is the level of identification of large or small companies owned. Large companies usually do more activities and have a large impact on their stakeholders and also have a higher public demand for information than smaller companies. This is because a large number of stakeholders in Sharia banks are Muslims and they need to fulfill information activities. The size of the company tends to affect the company's decision to open information in the annual report. The ISR in the annual report is significantly related to company size and the disclosure value is higher for large companies that are performing well (Lestari, 2013).

Lestari (2013) also Ummiyati and Baiquni (2018) revealed that company size had a significant effect on ISR disclosure while Lestari's (2016) study revealed that firm size had no significant effect on it at all. The ISR disclosure is not based on company size alone because total assets and total revenue are not its only sources. Based on the description above, the researchers formulated the hypothesis as follows:

$\mathbf{H}_{2}$ : Company size influences Islamic social reporting.

\section{Influence of Company Age on Islamic Social Reporting}

The age of the company is seen from how long the company has been standing. Companies that have been operating for a long time tends to have power in terms of the legitimacy of its environment. The length of time the company has operated illustrates that it has managed to survive in the competitive world of business and has won the sympathy of its stakeholders. The company has also succeeded in providing information that is in line with what is expected in its experiences to the environment or stakeholders. Companies with older ages tend to have more information, manage financial reports well and is able to control its internal and external circumstances (Lestari, 2016). 
Lestari (2013) shows that the age of the company has no significant effect on the disclosure of Islamic social reporting meaning that the older age, does not necessarily to increase ISR properly. In addition, in a study by Lestari (2013), it was explained that the age of the company had a significant effect on the disclosure of Islamic social reporting. The researcher formulated the hypothesis as follows:

$\mathbf{H}_{3}$ : The influence of company age on Islamic social reporting.

\section{METHOD}

\section{Population and Sample}

The population in this study are all Sharia Commercial Banks in Indonesia and Islamic banks are also used with several consideration that includes; (1) The purpose of Islamic banks is not only to maximize profits but also to maximize non-profit performance like the maqashid sharia. (2) There is little research that examines the effect of the maqashid sharia index on Islamic social reporting in Islamic banks in Indonesia. This study used a purposive sampling technique which is a sampling that is based on certain criteria. First, sharia commercial bank published financial statements and corporate social responsibility or management performance for 4 years in the 2015-2018 period because that year has a relevant data. Second, data related to the measurement of the maqashid sharia index, company size, company age, and Islamic social reporting are available in the annual report.

\section{Variables and Indicators}

This study used an Islamic social reporting, dependent and independent variable research consisting of the maqashid sharia index, company size, and company age. Data on each variable is observed through the annual report of each Islamic bank and the variable model is reflective.

Maqashid sharia index in this study used 10 ratios that measure 3 indicators, namely education (tahdzibul fard), justice (iqamatul 'adl), and welfare (jalbul maslahah). According to Mohammed et al. (2008), Jazil and Syahruddin (2013), Kholid and Bachtiar (2015), Mohammed, Tarique, and Islam (2015), Mohammed and Taib (2015) and Saoqi (2017), indicators are reference.

The Islamic social reporting level in this study refers to Haniffa (2002) with five indicators which include: Finance \& Investment, Products, Employee, Society, and Environment. He is a reference for further researchers such as Othman et al. (2009) and Othman and Thani (2010). Islamic social reporting from this study used content analysis, referring to Othman and Thani (2010). If the item is disclose by the Islamic bank then it is given a value of 1 and if on the other way round, it tends to be given the value of 0 . 


\section{Data Analysis Technique}

Statistical analysis in this study uses the Partial Least Square (PLS) approach with smartPLS software version 3.0. PLS is an alternative approach that shifts from a covariance-based SEM approach a variant-based (Ghozali \& Latan, 2015). It is used to confirm the theory, and explain the presence or absence of relationships between latent variables. Partial Least Square is used in this study because the sample size is relatively small, namely 11 Islamic banks in Indonesia with a research period of 4 years (2015-2018).

In testing the convergent validity, this study used a loading factor greater than 0.50 . The outer $\mathrm{r}$ model or measurement model define how each block of indicators relates to its latent variable. Also, the testing of the outer model was conducted by looking at the cross-loading factor, discriminant validity, and composite reliability of the construct. The construct is considered to have internal consistent reliability if the composite reliability is above 0.70 . R2 ( 2 value) of 0.75 , 0.50 , or 0.25 for endogenous latent variables in the structural model are described respectively as strong, moderate, or weak referring to the study of Hair, Anderson, Tatham and Black (2011).

Hypothesis testing was done by using bootstrapping to assess the significance of the path coefficient. The t-statistic value is greater than 1.96, so the hypothesis is accepted and vice versa. In addition, tends to be seen from the p-value if the value is less than 0.05 then the research hypothesis is accepted and vice versa (Hair et al., 2011).

\section{RESULTS AND DISCUSSION Descriptive Statistics}

Descriptive statistics in this study include the mean, minimum, maximum, and standard deviation. The results of the descriptive analysis are presented in Table 1.

Table 1. Descriptive Statistics

\begin{tabular}{|c|c|c|c|c|}
\hline No. Indicator & Mean & Min & Max & $\begin{array}{l}\text { Standard } \\
\text { Deviation }\end{array}$ \\
\hline 1 Education (X1.1) & 0.002 & -0.008 & 0.015 & 0.004 \\
\hline 1 Justice (X1.2) & 0.223 & -0.037 & 0.931 & 0.138 \\
\hline 2 Welfare (X1.3) & 0.092 & -0.009 & 0.129 & 0.021 \\
\hline 3 Total Assets (X2.1) & 2.192 & 0.066 & 9.834 & 2.606 \\
\hline 4 Total Revenue (X2.2) & 1.805 & 0.061 & 7.689 & 2.049 \\
\hline 5 Company Age (X3.1) & 7.136 & 1 & 11 & 2.341 \\
\hline 6 Finance and Investment (Y1.1) & 0.693 & 0.500 & 1 & 0.170 \\
\hline 7 Products and Services (Y1.2) & 0.871 & 0.333 & 1 & 0.204 \\
\hline 8 Employees (Y1.3) & 0.696 & 0.455 & 0.909 & 0.082 \\
\hline 9 Society (Y1.4) & 0.807 & 0.3 & 1 & 0.189 \\
\hline 10 Environment (Y1.5) & 0.541 & 0.2 & 0.8 & 0.198 \\
\hline
\end{tabular}




\section{Convergent Validity Testing}

Convergent validity testing is done by looking at the value of the outer loading of each research indicator. Outer loading is above 0.50 .

Table 2. Outer Loading Results

\begin{tabular}{llc}
\hline No. & Indicator & Outer Loading \\
\hline $\mathbf{1}$ & Justice $\quad(\mathrm{X} 1.2)$ & 0.839 \\
\hline $\mathbf{2}$ & Welfare $\quad(\mathrm{X} 1.3)$ & 0.664 \\
\hline $\mathbf{3}$ & Total Assets $(\mathrm{X} 2.1)$ & 0.996 \\
\hline $\mathbf{4}$ & Total Revenue (X2.2) & 0.996 \\
\hline $\mathbf{5}$ & Company Age (X3.1) & 1,000 \\
\hline $\mathbf{6}$ & Finance and Investment (Y1.1) & 0.651 \\
\hline $\mathbf{7}$ & Products and Services (Y1.2) & 0.721 \\
\hline $\mathbf{8}$ & Employees (Y1.3) & 0.825 \\
\hline $\mathbf{9}$ & Society (Y1.4) & 0.683 \\
\hline $\mathbf{1 0}$ & Environment (Y1.5) & 0.708 \\
\hline
\end{tabular}

Table 2 shows that this study used indicators of justice and welfare which represent the maqashid sharia index variable. The indicator of total assets and income represents the variable company size and that of the company age represent the long time the company has been existing. The financial and investment indicators, products and services, employees, the community, and the environment represent Islamic social reporting variables because the indicator has a loading factor above 0.50 .

\section{Discriminant Validity Test}

Discriminant validity testing is done by looking at cross-loading that the value of the correlation variable in itself must be greater than the square root value of AVE.

Table 3. Discriminant Validity Test Results

\begin{tabular}{lcccc}
\hline & Company Age & Company Size & IMS & ISR \\
\hline Company Age & 1,000 & & & \\
\hline Company Size & 0.265 & 0.996 & & \\
\hline IMS & 0.194 & 0.032 & 0.891 & \\
\hline ISR & 0.326 & 0.511 & 0.367 & 0.722 \\
\hline
\end{tabular}

Table 3 shows that all variables have the highest correlation on themselves compared with other variables and due to this, the discriminant validity measurement model is fulfilled. One example is the company age variable which has a value of 1,000 and this shows a high correlation compared with other variables that is equal to -0.265 (Company Size), 0.194 (IMS), and 0.326 (ISR). 


\section{Reliability Testing}

Reliability testing in this study was carried out using cronbach alpha and composite that are used to measure the reliability of reflexive measurement models and the rule of tumbs is 0.70 . Based on the results of the reliability test, the IMS, Company size, company age, and ISR variables have good results because the scores held are more than the rule of tumbs 0.70 .

Table 4. Reliability Testing Results

\begin{tabular}{lcc}
\hline Variable & Composite Reliability & Cronbach Alpha \\
\hline Company Age & 1,000 & 1,000 \\
\hline Company Size & 0.996 & 0.992 \\
\hline IMS & 0.885 & 0.750 \\
\hline ISR & 0.884 & 0.768 \\
\hline
\end{tabular}

\section{Structural Model Test Results}

The main criteria for assessing the inner model is to look at the coefficient of determination or $\mathrm{R}^{2}$. $\mathrm{R}^{2}$ values of $0.75,0.50$, or 0.25 for endogenous latent variables in the structural model are described respectively as strong, moderate, or weak. The $\mathrm{R}^{2}$ value of $55.7 \%$ on the variable level of Islamic social reporting disclosure as the dependent variable shows that the model is of medium category. The $\mathrm{R}^{2}$ value indicates that the variable level of Islamic social reporting disclosure are explained in the research model by $55.7 \%$ and the remaining $44.3 \%$ based on the calculation results obtained $\mathrm{Q}^{2}$ of 0.557 or $55.7 \%$. Following the criteria, this model shows that endogenous constructs have predictive relevance because they have a $Q^{2}$ value greater than zero.

\section{Hypothesis Test}

Hypothesis testing of the direct effect $\left(\mathrm{H}_{1}-\mathrm{H}_{3}\right)$ is done by looking at the value in the path of coefficients which show the parameter coefficient and the T-statistic value. The research hypothesis supported absolute T-statistic values $\geq 1.96$ or P-value $\leq 0.05$.

Table 5. Hypothesis Testing Results

\begin{tabular}{ccccc}
\hline Hypothesis & Original Sample & T-statistic & P-value & Results \\
\hline H 1 & 0.262 & 2,406 & 0.016 & Significant \\
\hline H 2 & 0.620 & 6,538 & 0.000 & Significant \\
\hline H 3 & 0.440 & 3,448 & 0.001 & Significant \\
\hline
\end{tabular}

\section{Effect of Maqashid Sharia Index on Islamic Social Reporting}

The maqashid sharia index in this study uses 2 (two) indicators, namely justice and welfare. Judging from the indicators of justice all banks have been revealed very well, Sharia banks are very concerned about justice in the transactions carried out. Also, the welfare indicators is when several banks do not disclose zakat such as Bank Panin Syariah (2018), Bukopin Syariah Bank 
(2015-2018), and Maybank Syariah (2015-2018). If the maqashid sharia Index has a high score, it tends to have an impact on the disclosure of Islamic social reporting. The testing of hypothesis states that the maqashid sharia index has a positive effect on the level of disclosure of Islamic social reporting.

This is in line with the theory of legitimacy whereby Sharia banks who want to be accepted by the public tends to fulfill social contracts through information disclosure. Sharia banks that are performing well are to express social responsibility at a higher level to gain trust from the public, so that Sharia banks are able to maintain their performance in the future.

\section{Effect of Company Size on Islamic Social Reporting}

The size of the company where the variable score is high, banks tend to disclose Islamic social reporting more broadly. Company size will influence decision of the bank to open information in annual reports. The testing of hypothesis states that company size has a positive effect on the level of disclosure of Islamic social reporting. Research empirically proves that Sharia banks that have total assets and high total income is able to make extensive Islamic social reporting disclosures because there are more sources of funds used for disclosure.

This is also in line with stakeholder theory where the total assets and revenue owned by a large Sharia bank are allocated to make extensive Islamic social reporting disclosure that tends to it will have a major impact on stakeholders. Employees continue to improve their performance to obtain assets and revenue that increases. Disclosure of Islamic social reporting is an obligation on the part of Sharia banks and the expectations of stakeholders to disclose information as a form of accountability to Allah SWT and meet the needs of muslim stakeholders. The increase in total assets and income of Sharia banks indicates that they have received legitimacy from the public so that sharia banks are able to survive and continue to grow from year to year.

\section{Influence of Company Age on Islamic Social Reporting}

Company age is used to see whether a long-standing Sharia bank is able to express Islamic social reporting properly or not. The testing of hypothesis states that company age has a positive effect on the disclosure of Islamic social reporting. This research empirically proves that the longer the banking system is established, the higher the level of Islamic social reporting disclosure.

Sharia banks that have long been operating tends to have the power to legitimize the surrounding environment and understand the information needs by its stakeholders. one of the information needed is about Islamic social reporting which banks continue to improve its program from year to year in order to gain legitimacy or trust in the community. The banking 
system that has long been established tends to know more about the state of the company. On the other hand, it does not only know the state of the environment internally, but also understand the state of the environment externally.

\section{CONCLUSION}

This study aims to examine the influence of the maqashid sharia index, company size, and company age on Islamic social reporting in the commercial banks of Indonesia in the 2015-2018 period. This study uses secondary data obtained from the official website of each bank and OJK website. The number of Islamic commercial banks in this study were 11 (eleven) banks.

This study has obtained empirical evidence that the maqashid sharia index, company size, and company age have a positive effect on Islamic social reporting in the commercial banks of Indonesia in the 2015-2018 period. This is supported by hypothesis testing which shows significant results.

In the maqashid sharia index variable there are two valid indicators, namely justice and welfare. The results of this study indicate that the higher the maqashid sharia index, company size, and company age owned by the company that the Islamic social reporting is disclose widely. The existence of Islamic social reporting tends to be a solution for regulators as a new sharia bank in implementing corporate social responsibility reports with a sharia perspective.

\section{LIMITATIONS AND SUGGESTIONS}

This study has several limitations that affect its result and the data relating to the maqashid sharia index variables and Islamic social reporting in commercial banks are not complete in annual reports. There are a lot of sharia banks that do not disclose education indicators, such as research ratios while the training costs ratio is the same as the education ratio.

Based on the limitations and results of this study, the researcher tends to provide suggestions for further researchers. For future researchers, if they want to see the same topic as this research, they suggests adding variables that affect the level of Islamic social reporting disclosure in different years or using different research samples.

\section{BIBLIOGRAPHY}

Deegan, C. 2002. Introduction: The Legitimising Effect of Social and Environmental DisclosureA Theoritical Foundation. Accounting, Auditing, and Accountability Journal, 5(3), 282 - 311. Dewi,A. S. M., \& Wirajaya, A. (2013). Pengaruh Struktur Modal, Profitabilitas, dan Ukuran Perusahaan Pada Nilai Perusahaan. E-Jurnal Akuntansi, 4(2), 358-372. 
Dienes, D., \& Velte, P. (2016). The Impact of Supervisory Board Composition on CSR Reporting: Evidence from the German Two-Tier System. Sustainability, 8(63), 1-20.

Firdaus, I. (2017). Pengaruh Kinerja Keuangan, Kepemilikan Institusional, Ukuran Dewan Pengawas Syariah, Leverage Terhadap Pengungkapan Islamic Social Reporting Pada Perbankan Syariah di Indonesia. JOMFekon, 4(1), 3095-3109.

Fitria, S., \& Hartanti. (2010). Islam dan Tanggung Jawab Sosial: Studi Perbandingan Pengungkapan Berdasarkan Global Reporting Initiative Indeks dan Islamic Social Reporting Indeks. Simposium Nasional Akuntansi XIII.

Ghazali, I., \& Latan, H. (2015). Partial Least Squares: Konsep, Teknik dan Aplikasi Menggunakan SmartPLS 3.0, Edisi 2. Semarang: Universitas Diponegoro.

Hadi, N. (2009). Social Responsibility: Kajian Theoratical Framework dan Perannya dalam Riset di bidang Akuntansi. Akses: Jurnal Ekonomi \& Bisnis, 4(8), 88-109. doi: 10.31942/ akses.v4i8.517.

Hair, J. F., Anderson, R. E., Tatham, R. L., \& Black, W. C. (2011). Multivariate Data Analysis, Fifth Edition. New Jersey: Prentice Hall, Inc.

Haniffa, R. (2002). Social Reporting Disclosure An Islamic Perspective. Indonesian Management \& Accounting Research, 38(3), 128-146.

Haniffa, R., \& Hudaib, M. (2007). Exploring Rhe Ethical Identity Of Sharia bank Via Communication In Annual Reports. Journal of Business Ethics, 76, 97-116. doi: https://doi.org/10.1007/ s10551-006-9272-5.

Jazil, T., \& Syahruddin. (2013). The Performance Measures of Selected Malaysian and Indonesian: Islamic Banks based on the Maqasid al-Shari'ah Approach. Jurnal Hukum dan Ekonomi, 7(2), 279-301.

Juhmani, O. (2014). Determinants of Corporate Social and Environmental Disclosure on Websites: the Case of Bahrain. Universal Journal of Accounting and Finance, 2(4), 77 - 87.

Kholid, M. N., \& Bachtiar, A. (2015). Good Corporate Governance dan Kinerja Maqashid Syariah Bank Syariah di Indonesia. Jurnal Akuntansi dan Auditing Indonesia, 19(2): 126-136. DOI: https://doi.org/10.20885/jaai.vol19.iss2.art4.

Lestari, P. (2013). Determinants of Islamic Social Reporting In Syariah Banks: Case of Indonesia. International Journal of Business and Management Invention, 2(10), 28-34.

Lestari, S. (2016). Pengaruh Tingkat Profitabilitas, Likuiditas, Leverage, Ukuran Perusahaan dan Umur Perusahaan Terhadap Pengungkapan Islamic Social Reporting Pada Perbankan Syariah Indonesia Tahun 2010-2014. Jurnal Akuntansi Akunesa, 4(2), 1-24. 
Maali, B., Casson, P., \& Napier, C. (2006). Social Reporting by Islamic Banks. Abacus, 42(2), 266-289.

Mohammed, M. O., Razak, D.A., \& Taib, F. Md. (2008). The Performance Measures of Islamic Banking Based on The Maqashid syariah. Proceeding IIUM International Accounting Conference (INTAC IV).

Mohammed, M. O., \& Taib, F. Md. (2015). Developing Islamic Banking Performance Measures Based on Maqasid A1-Shari'ah Framework: Cases of 24 Selected Banks. Journal of Islamic Monetary Economics and Finance, 1(1), 55-77.

Mohammed, M. O., Tarique K. Md., \& Islam, R. (2015). Measuring the Performance of Islamic Banks using Maqasid-Based Model. Intellectual Discourse, 23, 401-424.

Rama,A., \& Meliawati. (2014). Analisis Determinan Pengungkapan Islamic Social Reporting. Equilibrium, 2(1), 84-103.

Salman, K. R.,Anshori, M., \& Tjaraka,H. (2018). New Evidence on the Direct and Indirect Influence on the Maqashid Sharia Index on the Islamic Social Reporting Index. International Journal of Research Science and Management, 5(8), 165-173. doi:10.5281

Saoqi,A.A. (2017). Analyzing The Performance of Islamic Banking In Indonesia and Malaysia: Maqashid Index Approach. Jurnal Ekonomi Islam, 8(1), 29-50.

Sunarsih, U., \& Ferdiyansyah. (2017). Determinants of the Islamic Social Reporting Disclosure. Al-Iqtishad: Jurnal Ilmu Ekonomi Syariah, 9(1): 69-80.

Syukron,A. (2013). Dinamika Perkembangan Perbankan Syariah di Indonesia. Economics: Jurnal Ekonomi dan Hukum Islam, 3(2), 28-53.

Othman, R., Thani,A. Md., \& Ghani, E. K. (2009). Determinants of Islamic Social Reporting Among Top Shariah-Approved Companies in Bursa Malaysia. Research Journal of International Studies, 12(12), 4-20.

Othman, R., \& Thani, A. Md. (2010). Islamic Social Reporting of Listed Companies in Malaysia. International Business \& Economics Research Journal, 9(4): 135-144.

Ummiyati, \& Baiquni, M. D. (2018). Ukuran Perusahaan, Profitabilitas, dan Leverage Terhadap Islamic Social Reporting Pada Bank Umum Syariah di Indonesia. Jurnal Akuntansi dan Keuangan Islam, 6(1), 85-104.

Utami, S., \& Prastiti, S. D. (2011). Pengaruh Karakteristik Perusahaan Terhadap Social Disclosure. Jurnal Ekonomi Bisnis, 16(1), 63-69.

Usman, A., \& Khan, M. K. (2012). Evaluating the Financial Performance of Islamic and Conventional Banks of Pakistan: A Comparative Analysis. International Journal of Business and Social Science, 3(7), 253-257. 
Wiyuda,A., \& Pramono, H. (2017). Pengaruh Good Corporate Governance, Karakteristik Perusahaan terhadap Luas Pengungkapan Corporate Social Responsibility pada Perusahaan Terdaftar di BEI. Kompartemen, 15(1), 12-25. (2019, March 15). Retrieved from Statistik Perbankan Tahun 2019: www.ojk.go.id 